\title{
Information literacy for inquiry-based learning
}

\author{
Letramento informacional: em direção \\ ao método de projetos
}

Kelley Cristine Gonçalves Dias GASQUE'1

\begin{abstract}
Given the importance of focus on globalized curriculum, this study presents a review of the literature on issues related to the nature of learning contents and curriculum, especially the development of curriculum based on the research process - inquirybased learning - in terms of information literacy. Some hypotheses were formulated to explain the lack of studies on this topic, such as the level of development of information literacy programs, pedagogical training of librarians, and educational institutions' perceptions of the importance of information literacy. Recommendations for further research on the topic were made. It was concluded that inquiry-based learning allow better integration of information literacy content providing more meaningful learning by encouraging reflection, student protagonism, and learning how to learn among others.
\end{abstract}

Keywords: Curriculum. Information literacy. Learning contents. Projects method.

\section{Resumo}

Ao considerar a importância dos enfoques globalizadores curriculares o presente artigo apresenta revisão de literatura sobre questões relacionadas à natureza dos conteúdos de aprendizagem e ao currículo, em especial, à elaboração curricular por meio do processo de pesquisa - método de projetos no contexto do letramento informacional. Levanta hipóteses para explicar a escassez de artigos sobre o assunto, quais sejam, grau de maturidade dos programas de letramento informacional, formação pedagógica dos bibliotecários e a percepção das instituições educacionais sobre a importância do letramento informacional. Recomenda investir em mais pesquisas sobre o assunto. Conclui que o método de projetos permite melhor inserção dos conteúdos de letramento informacional, propiciando aprendizagem mais significativa por favorecer a reflexão, o protagonismo do estudante e o aprender a aprender.

Palavras-chave: Currículo. Letramento informacional. Conteúdos de aprendizagem. Método de projetos.

\section{Introduction}

Informational Literacy (IL) can be understood as the teaching-learning process needed to develop competences in order to seek for and use information effectively and efficiently (Gasque, 2012). This requires the integration and organization of IL into the educational curriculum, which can be structured in different ways.

In the study "Curriculum and imagination", McKernan (2009) identified six models of curriculum design: development of disciplines and subject-centered

\footnotetext{
1 Universidade de Brasília, Faculdade de Ciência da Informação, Programa de Pós-Graduação em Ciência da Informação. Campus Universitário Darcy Ribeiro, Asa Norte, 70919-970, Brasília, DF, Brasil. E-mail: <kelleycristinegasque@hotmail.com>.

Received in 6/16/2014 and approved in 1/5/2016
} 
curriculum, development of interdisciplinary topics, development of a student- or child-centered curriculum, development of a core curriculum, development of an integrated curriculum, development of a processcentered curriculum, development of a humanistic curriculum.

The most traditional curriculum development is based on the concept that knowledge is divided into fragmented subjects organized by disciplines, for example, mathematics, science, and physics. The approach to curriculum development based on knowledge or fields of knowledge includes related disciplines organized in the same field. For example, social studies is a field of study that includes history, geography, economics, and sociology. The IL content can be organized into two different ways in these two types of curriculum. The first is based on the the creation of a new discipline within the curriculum. The second is based on the distribution of IL contents into the disciplines or subjects. In addition, IL contents can be taught in extracurricular activities that are complementary to the existing curriculum. Another curriculum structure is the learner-centered curriculum. In this case, the IL contents should be organized according to the learner's interests and needs. The curriculum can have a core structure, in which the core is the set of common knowledge and courses that are considered essential for learning. This type of curriculum is adopted in many countries and includes the national knowledge core for basic education, which, in this case, should also include IL contents.

Another type includes the integrated curriculum organized around a theme, which allow teachers of different disciplines to teach the same subject unifying concepts, according to the literature or textbooks of each branch of study. In this curriculum model, the themes should be taught combined with one or more IL contents, for example: "public health information search procedures". On the other hand, the humanistic curriculum is based on values, customs, and the existential question of how to live one's life. This type of curriculum should emphasize more attitudinal aspects of IL. And finally, the development of process-centered curriculum is based on the procedures by which students can carry out investigations focusing more on learning how to learn than on the discipline content. In addition to the models identified by McKernan (2009), a curriculum model can integrate features of one or more models.

The informational literacy contents are organized according to the educational institution context, teaching-learning concepts, and human, structural and financial resources among others. It is worth noting that, in recent decades, in general, learning or curriculum contents have been distributed primarily based on disciplinary parameters. This fact, according to Zabala (2002), is related to the scientific context in which science development processes led to the fragmentation of knowledge. However, the author points out that the purpose of education is different from that of science, and therefore it is important to consider globalized approaches, such as project-based work. In addition, according to McKernan (2009, p.100), "the literature on curriculum has established the objectives model as the paradigm for curriculum planning, which has been the most widely used model". This fact is related to the significance given to technical rationality and education, which have been considered as science since the first decades of the twentieth century.

According to the Australian and New Zealand Institute for Information Literacy (ANZIIL) in a publication released in 2004, the most effective way of learning is by the transversal ${ }^{2}$ integration of the IL contents into the curriculum allowing students to interact with information and reflect on the practice. Harada and Yoshina (2004); Hmelo-Silver et al. (2007); Chu et al. (2011); McKinney (2013), among others, argue that there is evidence pointing to the effectiveness of pedagogical approaches based on projects for the improvement of learning outcomes.

Based on the educational literature on the importance of globalized approaches, specially, in terms of inquiry-based learning as a curriculum development model (Hernandez \& Montserrat, 1998; Zabala, 2002; McKernan, 2009), the present study presents a review of the literature on topics related to the nature of learning content and curriculum, particularly the development

\footnotetext{
2 According to the Parâmetros Curriculares Nacionais (PCN, National Curriculum Parameters), transversality entails the integration of different areas, allowing a relationship between systematized knowledge and real life situations (Brasil, 1997).
} 
of curriculum based on research process - inquiry based learning - identifying studies that address the relationship between research-based projects and IL. The main objectives of this study are to stimulate discussion regarding the possibilities of integrating $\mathrm{IL}$ into the curricula of basic education and contribute to the literature in the field since the international literature available regarding this topic is scant and practically nonexistent in Brazil.

\section{Information Literacy Learning contents and curriculum}

Learning content can be understood roughly as the subjects, themes, or topics to be taught in the learning process. Therefore, learning contents are directly related to educational objectives.

Zabala (1998) argues that the contents represent the educational intentions, i.e., they are related to "what to teach" and "what to learn" to achieve certain goals. Additionally, the learning contents are also related to the question "why teaching". Contents can be techniques, skills, attitudes, concepts, etc. Coll (1986) proposed the following content classification:

a) Conceptual content: encompass facts, concepts, and principles (what one should know);

b) Procedural content: techniques and methods (what one should know how to do);

c) Attitudinal content: include values, attitudes, rules (how one should be).

According to Gasque (2012), IL contents should encompass the concepts, procedures, and attitudes that allow seeking for and using information effectively and efficiently. In general, the IL standards include skills in dealing with information, such as searching skills; proper use of information; and familiarity with information technology; generic skills, such as problem solving, collaboration and teamwork, communication, and critical thinking. Lastly, they include values and beliefs, i.e., information should be used wisely and ethically, promoting social responsibility and community participation (Australian and New Zealand Institute for Information Literacy, 2004).
The selection of teaching-learning contents indicate the purpose and importance attached by people and different countries to education; thus it is a dynamic and, at the same time, ideological activity. The reasons are that it is impossible to teach everything and there are constantly new contents to be taught. In many cases, the inclusion of new contents may replace older ones or result in a surplus of new contents and materials (Zabala, 2002). Furthermore, these contents should be considered in terms of learnability, i.e., according to the school level and the time available for learning.

It takes a lot more time to learn difficult topics and subjects. It is estimated that the chess grandmasters need 50 to 100 thousand hours of practice to reach the level of competence. Attempts to cover too many topics quickly may hinder learning and can result in: (a) learning of isolated sets of facts that are not connected and (b) lack knowledge of content organizing principles (Bransford et al., 2007).

As for the IL learning contents, it is important to remember that although the term "information literacy" first appeared in print in a 1974 report by Paul Zurkowski, there had been publications providing guidance on the use of school and public libraries since the 1920s in the United States. However, in 1988, the American Association of School Librarians and the Association for Educational Communications and Technology published "Information Power: building partnerships for Learning", expanding the focus to encompass lifelong learning and social responsibility.

Generally, the IL learning contents are based on competency standards, which include three basic components, access, evaluation, and use of information. These core goals are found in most of the standards created by library associations and information centers, such as the American Association of School Libraries (AASL), Association of College \& Research Libraries (ACRL), The Society of College, National and University Libraries (Sconul), and the ANZIIL in among others (Lau, 2006).

Curriculum planning based on competency standards results from current education reforms, in particular, from the 1980s onwards, whose standards establish benchmarks for what any student should know and be able to do. Competency-based education requires clear and measurable norms. Accordingly, 
curriculum, assessment, and professional development must be aligned to the competency standards (Hamilton et al., 2008). Therefore, the standards must present goals, support qualitative and quantitative criteria, norms, and include statements expressed in relative terms, relating performance to norms derived from a reference population (Association of College \& Research Libraries, 2012).

Several studies have investigated problems in structuring contents based on competency. The first line of research concerns quality standard, which has not always been well-structured and clear. The second investigates how this type of education affects the educational practice. Another issue is how to prevent excessive assessment. Finally, some studies have investigated student learning progressions associated with the use of this approach. Recent research has shown that there has been progress in learning, but for reasons that are not yet clear (Hamilton et al., 2008).

Many information literacy models undergo revisions to incorporate new perspectives. The model proposed by Sconul, for example, was revised in 2011. There are presently seven pillars based on two perspectives - theoretical and practical. That is, the learner must understand the issues of each pillar and be able to apply the knowledge. It is a three-dimensional circular model which indicates that the person is developing continually and holistically within the seven pillars. Information literacy is an umbrella term that encompasses concepts such as digital, visual, and media literacies, information handling, information skills, and data management.

The Association of College \& Research Libraries (2000) IL model for higher education includes five competency standards: (1) determine the extent of information needed; (2) access the needed information effectively and efficiently; (3) evaluate information and its sources critically; (4) incorporate selected information into one's knowledge base; and (5) use information effectively to accomplish a specific purpose considering ethical, legal, and economic aspects. The framework published in 2000 has been recently revised. The ACRL has recognized that the original standards do not provide enough guidance on visual and digital literacies, often considered subsets of information literacy itself. Furthermore, with the review of IL objectives for basic or primary education, the original ACRL IL model do not provide a continuum of learning for students moving from primary education to higher education.

Accordingly, the new IL standards should be simplified, allow greater flexibility, eliminate library jargons, include attitudinal learning outcomes, in addition to the exclusively cognitive focus of the current standards. It should also include also other types of literacy, address the role of the student as content creator and curator, and provide continuity with the proposed standards for basic education (Association of College \& Research Libraries, 2012).

According to the recommendations of Australian and New Zealand Institute for Information Literacy (2004) and Lau (2006), as previously mentioned, there should be transversal integration of the IL contents into the curriculum. Therefore, it is necessary to understand how transversality occurs and how transversal topics are addressed. In educational reforms in many countries, there is a need to include the development of human values, such as citizenship, ethics, and ecology among others. These topics should not replace those previously included in the classical academic disciplines, and they should not be an "addendum" to the official curriculum, but rather "dimensions", which should form the basis for the development of the curriculum (Yus Ramos, 1998).

Yus Ramos (1998) highlights that although transversality refers to curricular complexity and globalization, this practice has been interpreted differently by curriculum developers: as a set of moral norms combined with specific disciplines, for example, philosophy/ethics; as new disciplines linked to the classic disciplines but are scheduled separately; as separate didactic units incorporated to the academic content; as topics or subjects associated with special supplementary issues (environment day and non-violence day); as optional subjects to be included in the disciplines or not; as topics to be equally distributed into the disciplines, promoting the integration between subjects and disciplines; as a topic diluted in the curriculum and isolated topics that are not related to each other. The author points out that these interpretations are wrong and often lead to the trivialization of transversal topics or have a purely aesthetic effect. 
Sancho (1998) emphasizes that the need to teach using transversal topics, without questioning the basic teaching organization and the methods of teaching and without making any changes in school management including them into the regular schedule, has undermined the meaning of transversality as the central axis of pedagogical experience. Therefore, it is necessary to determine the best way to integrate IL contents into the curriculum in order to achieve effective and meaningful learning.

The word curriculum derives from Latin currere, literally meaning "to run the course". Curriculum has been studied by various authors, such as Dewey (1902; 1910; 2010); Stenhouse (1975); Hernandez and Montserrat (1998); Zabala, (2002) and McKernan (2009). With reference to Saviani (2003), it can be broadly understood as the selection, sequence, and organization of the contents to be developed in teaching-learning situations. It includes knowledge, ideas, habits, values, techniques, resources, devices, procedures, and symbols depicted in school subjects/disciplines, indicating activities/experiences for learning consolidation and evaluation.

There is need for intensified research on $I L$ and curricular issues in the field of information science. The reason is that grasping the concept of curriculum, as well as the selection and sequence of contents, the distribution of contents by grade level or age, the limitations of traditional approaches, and the feasibility of alternative proposals, are crucial issues to integrate IL contents into school and academic contents.

In Brazil, there are few articles available on this topic, and they address how library science courses integrate IL into their curricula (Lins, 2007; Sousa \& Nascimento, 2010). This may show the level of application of this process in the educational context and the difficulties faced by researchers and librarians concerning psycho-pedagogical aspects of teaching and learning.

According to the literature, even in countries where there is more research on $\mathrm{I}$, there are many programs in an experimental stage and few have been integrated in a cross-curricular manner. Harris (2013), for example, investigated the integration of IL contents into the curriculum of Quality Enhancement Plan (QEP) of The Southern Association of Colleges and Schools (SACS), between 2004 and 2011. The author organized 106 QEP proposals into three categories based on the focus given to IL goals, outcomes, and assessment: IL-Focused Proposals; IL-Integrated Proposals; IL-Optional Proposals. In the first case, IL development was the stated goal of the proposal. In this category, 18 proposals were identified. In the second case, including 58 proposals, IL was one of the primary goals and/or outcomes identified in the proposal. Finally, in the last category, IL was not listed as a stated goal of the plan although outcomes or IL instruction are included as optional or incidental components of the QEP; thirty proposals were identified in this category. Based on the results of the IL proposals, it was observed that the majority (37) included one or more learning outcomes related to the evaluation of information sources. The author concluded that the teaching plans focused on critical thinking, on the use of information to accomplish a goal, and on the location and effective and efficient selection of sources.

The little flexibility of traditional models is a factor that hinders the integration of IL contents into the curriculum. McKernan (2009) argues that the technical and rational curriculum model, the dominant model since the twentieth century, emphasizes the ends-means rational planning by instructional-behavioral objectives.

Accordingly, several authors have questioned the traditional models showing the need to organize the curriculum based on alternative approaches. Some studies show that traditional curricula does not help students "learn their way around" a discipline. They only provide routine training without teaching them to understand the whole picture; which does not ensure the development of integrated knowledge structures and applicability conditions. In other words, the traditional curricula specify objectives, which are not always considered part of a larger network; yet it is the network, connections among objectives, that is important (Bransford et al., 2007).

Zabala (2002) is one of the authors that has questioned the traditional curriculum, identifying the need for a globalizing approach. The author's justification is based on research on human perception, associating knowledge with understanding situations from a global point of view due to the need to respond to tackle problems or a particular situation. Furthermore, in order 
for learning to be meaningful for students, it must be motivating, that is it should be based on learners'interest.

The problem of curriculum design is to lead students to experience and understand things that truly matters in life (McKernan, 2009). Such an approach, proposed by Dewey (1902; 1910; 2010), sets out two principles of the progressive organization of curriculum materials. The first principle is that the teaching content should be based on common experiences of life. The second refers to the relationship between the progress of the content taught and students' maturity level. Among various educational recommendations, the author argues that "learning should be based on the internal conditions of an experience that leads to an active search for information and new ideas" (Dewey, 2010, p.82).

Zabala (2002) presents several globalized curriculum methods; however, according to the author's opinion, due to their historical and present importance, the most relevant are the Decroly's centers of interest, the Kilpatrick's inquiry-based learning the Movimento di Cooperazione Educativa (MCE), and globalized projectbased work. The difference between these methods lies in the emphasis of students' efforts and production, as well as in didactic sequences.

Among the aforementioned methods, inquirybased learning and global project-based work methods stand out since they are the most commonly researched and used methods for curriculum organization and IL process development.

\section{Information literacy projects}

According to Dewey $(1910 ; 2010)$ projects are a method to develop reflective thinking. Projects must be related to students' experiences. The author argued that sound educational experience involves continuity and interaction between the learner and what is learned. Therefore, the author criticized the traditional curriculum for its rigid organization and because it disregards the capacities and interests of learners.

Dewey' (2010) proposal focused on teaching through real life activities because isolated teaching, disconnected from students' experience, does not prepare students for the real world. Accordingly, schools should work as a small community, with students involved in real life activities, creating opportunities for contribution and responsibility. Thus, learning would occur through problem solving, which involves the scientific method. The scientific method facilitates the formulation of concepts and explanatory theories since it includes the observation and data collection to select accurate facts. The reason is because it relies on several processes that tend to avoid hasty conclusions and are based on a proper understanding of meaning of things or topics.

In the study "Experience and education" (2010), Dewey uses the term "purpose" with a similar meaning to projects. Purpose is what you intend to achieve; thus it involves foreseeing the consequences of an action, which is an intellectual operation. Such action involves observation, understanding the significance of what is observed, judgment, and planning.

Teaching based on the learner's interests and experiences was the core value of progressive schools. However, Dewey (2010) stated that some of them misunderstood the-concept since "projects" were not always educational projects. To be considered educational, they must fulfill four conditions. The first is based on the interest of students. The second refers to the intrinsic value of the project, that is, it should please and at the same time"represent something that is worth for itself in life" (Dewey, 1910, p.217). The third condition is to introduce problems which arouse curiosities and require information search. Lastly, the project should last for a reasonable amount of time to allow proper implementation. Moreover, the project should be an ongoing process and not a series of disconnected facts.

Dewey's pedagogical beliefs were not restricted to the theoretical field. In 1896, Dewey opened the University of Chicago's Laboratory School, an experimental school, to put his pedagogical ideas into practice. According to Westbrook (1993) at the center of the curriculum of the School was what Dewey termed the "occupation", that is, a mode of activity on the part of the child which reproduces, or runs parallel to, some of work carried on in social life. However, this school was not designed for the social reproduction, but rather to develop cooperative critical citizens for a democratic society. Students learned to do: to cook, to sew, to work with wood and tools. Along with these activities, writing, 
reading, geography and arithmetic contents, among others, were developed, that is, when students recognized their usefulness to solve problems that confronted them in their occupational activities. Students shared in the planning of their projects, and the execution of these projects was marked by a cooperative division of labor, in which leadership roles were frequently rotated. Providing children with first-hand experience with problematic situations is the key to Dewey's pedagogy.

Kilpatrick is recognized for structuring and disseminating the inquiry-based learning method, but it was John Dewey who first applied it in an experimental school of the University of Chicago. The projects were characterized by functionality, influence of Stanley Hall evolutionism, the theory of Thorndike's constructivist learning theory, and Dewey's socialist theories (Zabala, 2002).

More recently, the projects have taken on a new configuration and name: global project-based work. Some authors see them as a progression of Project Works, aiming at the globalization of school content (Zabala, 2002). Hernandez and Montserrat (1998) "rediscovered" the projects and reported their experience with curriculum development through projects at the Universitat Pompeu Fabra, Barcelona, Spain. The authors concluded that learning how to learn was the focus of the experience, but cultural, personal, and idiosyncratic issues cannot be hidden under the eyes of students and teachers' affection. They added that, despite the insistence on teaching-learning processes, there should be concern with the outcomes, based on reflection and not only in the measures. Their study has been cited in several articles and research in Brazil, perhaps for being the first study to describe in detail the implementation of projects in a basic education school. This can help readers to envision a scenario with several important elements: actors, didactic and pedagogical issues, difficulties, and benefits among others.

In short, John Dewey's pedagogy requires more committed teachers, who have the ability to understand how students think and what they know; those that can plan their actions with flexibility and focus. This requires considerable changes, not only in the classroom but in the entire school, which is not always easy. It also requires a flexible curriculum design, focused on the student's everyday problems. This explains why Dewey emphasized the fact that the path towards new education is more resistant and difficult.

There are few studies on $\mathrm{IL}$ and inquiry-based learning in the field of information science. Reed and Straveva (2006) argue that IL teaching without a reflective thinking approach makes it a mere set of abilities. This statement was corroborated by Gasque (2006; 2008; 2012), who showed the importance of reflective thinking in the IL teaching through the use of research projects. This author sees projects as research processes aimed at solving problems. Within this perspective, they can be understood as a teaching-learning proposal focused on content globalization, i.e., the contents are addressed by topics and investigated in the classroom, where students are responsible for their own learning.

The inquiry-based learning originated from John Dewey studies, and more recently, the project-based work, understood as a reinterpretation of Dewey's proposal, are equivalent to research projects, based on the scientific method to solve problems. Both projects include, in general, identification of problems, hypothesis, objectives, justifications, information search, methodology, data collection, analysis, and conclusions. It is important to understand that in a research/investigation, the reflection on the elements and relationships established in the process should be emphasized so that they are fully understood. Moreover, the research topic should not be the focus of the investigation, neglecting the understanding of information use and search processes (Gasque, 2012).

Hepworth and Walton (2009) argue that the IL contents should be integrated into the curriculum through problem solving since it allows thorough reflection, promoting a more meaningful learning and didactic transposition to other contexts.

Although there is evidence of learning improvement through inquiry-based learning, according to Chu et al. (2011), there are very few studies on IL investigating the use of these strategies. For example, when searching on the Coordenação de Aperfeiçoamento de Pessoal de Nível Superior (Capes, Coordination for the Improvement of Higher Education Personnel) web

\footnotetext{
${ }^{3}$ Available from:<www.periodicos.capes.gov.br/>. Cited: Mar. 17, 2016.
} 
portal $^{3}$ only few articles were found using the terms "projects and information literacy"; "IL and Dewey"; "IL and Kilpatrick"; "IL and research-based learning". One of the few articles identified was written by Yu et al. (2011), who recognizes the potential of the use of projects to integrate IL. Their results show that teachers perceive IL as competencies of Information and Communication Technology (ICT) and that they do not teach the contents of IL during project supervisions. Moreover, only the basic contents of IL were integrated into the projects.

Harada and Yoshina (2004) emphasize the importance of inquiry-based learning. The authors identified eight important aspects of this type of learning, according to various articles: (1) learning experience is based on inquiry; (2) students help to negotiate the direction of what will be learned learning; (3) learning is social and interactive; (4) problem solving is integral part of the process; (5) students learn by doing; (6) results show the use of transfer of learning; (7) assessment is continuous, and (8) learning is authentic.

They also recommended that libraries contribute to the research process by: (1) helping students widen the initial research sources; (2) helping students raise more complex research questions using web search techniques; (3) helping students with research strategies using keywords and discussing the different types of resources used in research; (4) teaching effective note-taking strategies; (5) helping students synthesize contents through conceptual maps, flowcharts, etc.; and (6) helping teacher and students develop indicators to assess student performance throughout the research process and evaluate the process outcomes.

Three articles addressing the assessment of IL integration through research projects were identified. The article by Gehring and Eastman (2008), carried out in a biology course at the Connecticut College, evaluated the results of implementing $\mathrm{IL}$ through projects. The students were given an IL tutorial and carried out tasks using primary literature analysis integrated with laboratory research projects. The results show that the students increased their ability to identify and use adequate sources of information. In addition, standards used by students to seek and use information were identified. Self-assessment responses indicated that students recognized the impact of $\mathrm{IL}$ on their information skills and were more confident for future biology courses.
Another study, conducted by Chu et al. (2011), investigated the effect of the combination between the collaborative teaching approach with the inquiry-based learning for the development of information literacy and information technology skills in primary school. The results indicate that the program had a positive impact on the development of different dimensions of $\mathrm{IL}$ and information technology skills of the participants.

Finally, the study by McKinney (2013) reported the evaluation of development projects undertaken at a United Kingdom university focusing on IL and on the development of IL capabilities to support learning. The results showed that students developed individual IL capabilities and learned how to effectively use library resources. The students also recognized the importance of IL for their personal and professional life. Moreover, the results also showed the importance of considering the development of $\mathrm{IL}$ in the context of projects. Within this perspective, librarians and IL experts should actively participate in the project development. The author points out that the inquiry-based learning focused on the development of IL need to contextualize subjects that are meaningful to students. Teachers need to explain to the students that IL development is the focus of specific activities and discuss the concept of IL with them.

Although there are many studies on the importance of the project-based pedagogy in the area of education, there are still few initiatives that relate this approach to the development of IL process. Additionally, the (few) studies identified in the literature review address projects carried out in a discipline; they do not focus on a curriculum change in order to globalize the contents. Furthermore, the three articles that assessed the implementation of projects integrated with IL content, did not evaluated the learning content. Ideally, project results should show improvement in the performance of search activities and use of information, as well as the discipline contents or topics covered.

As previously explained, some hypotheses to explain the lack of research in this area are related to the fact that only recently has this topic been investigated and to the often inadequate pedagogical training of librarians. Another hypothesis concerns the discussion of how the educational institutions and teachers perceive the importance of the IL process and how much they 
are willing to invest in it. This is reflected in the sequence and organization of IL contents into the curriculum, which are related to the teaching-learning concepts. Therefore, investing in research on this topic is of extreme importance.

\section{Conclusion}

The implementation of IL programs is linked to the sequencing and organization of content into the curriculum, which are related to the pedagogical concept. Although there are recommendations in the literature addressing the importance of integration of IL contents in a cross-curricular manner, it was observed that there this concept has been misunderstood. Due to their potential, the research/project methods enable better integration of IL contents into the curriculum, providing students with more meaningful learning by encouraging reflection, student protagonism, and learning how to learn among others. Yet, there is little research on Information Science and Education. Some hypotheses formulated to explain such situation are related to the level of development of IL programs, the pedagogical training of librarians, and to educational institutions' perceptions of the importance of IL. Finally, based on the aforementioned discussions, it is recommended to stimulate and support research on curriculum and IL, in particular, inquiry-based learning.

\section{Aknowledgements}

The authors are grateful to Dr. Isabel Cristina Michelan de Azevedo for her careful reading and suggestions that greatly improved this manuscript.

\section{References}

Association of College \& Research Libraries. Information Literacy Competency Standards for Higher Education. Chicago (IL): American Library Association, 2000. Available from: <http:// www.ala.org/acrl/standards/informationliteracycompetency \#stan>. Cited: Mar. 12, 2014.

Association of College \& Research Libraries. ACRL Information Literacy Competency Standards Review Task Force. Chicago (IL): American Library Association, 2012. Available from: <http:// www.ala.org/acrl/sites/ala.org.acrl/files/content/standards/ ils_recomm.pdf>. Cited: Apr. 16, 2014.

Australian and New Zealand Institute for Information Literacy. Australian and New Zealand information literacy framework. $2^{\text {nd }}$. Adelaide (SA): UniSA Library, 2004. Available from: <http:// www.library.unisa.edu.au/learn/infolit/infolit-2nd-edition. pdf>. Cited: Apr. 18, 2014.

Bransford, J.D.; Brown, A.L.; Cocking, R.R. (Org.). Como as pessoas aprendem. São Paulo: Senac, 2007.

Brasil. Secretaria de Educação Fundamental. Parâmetros curriculares nacionais: introdução aos parâmetros curriculares nacionais. Brasília: Mec/SEF, 1997. Disponível em: <http:// portal.mec.gov.br/seb/arquivos/pdf/livro01.pdf>. Acesso em: 23 abr. 2014

Chu, S.; Tse, S. Chow, K. Using collaborative teaching and inquiry project-based learning to help primary school students develop literacy and information skills. Library \& Information Science Research, v.32, n.2, p.132-143, 2011.

Coll, C. Marc curricular per a l'ensenyament obligatori. Barcelona: Paidós, 1986.

Dewey, J. The child and the curriculum. Chicago: London: The University of Chicago Press, 1902. Available from: <http:// www.gutenberg.org/files/29259/29259-h/29259-h.htm>. Cited: May 2, 2014.

Dewey, J. How we think. Boston: D.C. Heath and Company, 1910. Available from: <http://www.gutenberg.org/files/ 37423/37423-h/37423-h.htm>. Cited: May 1, 2014.

Dewey, J. Experiência e educação. Petrópolis: Vozes, 2010.

Gasque, K.C.G.D. O pensamento reflexivo na busca e no uso da informação. In: Encontro Nacional de Pesquisa em Ciência da Informação, 7., 2006, Marília. Anais... Marília: Unesp, 2006. p.432-440.

Gasque, K.C.G.D. O pensamento reflexivo na busca e no uso da informação na comunicação científica. Tese (Doutorado em Ciência da Informação) - Faculdade de Ciência da Informação, Universidade de Brasília, Brasília, 2008. Disponível em: <http:// bdtd.bce.unb.br/tedesimplificado/tde_busca/arquivo.php? codArquivo=3564>. Acesso em: 2 abr. 2014.

Gasque, K.C.G.D. Letramento informacional: pesquisa, reflexão e aprendizagem. Brasília: UnB, 2012. Disponível em: <http:// repositorio.unb.br/bitstream/10482/13025/1/LIVRO_ Letramento_Informacional.pdf>. Acesso em: 30 abr. 2014.

Gehring, K.M.; Eastman, D. The information fluency for Undergraduate Biology majors: Applications of inquiry-based learning in a Developmental Biology course. CBE-Life Sciences Education, v.7, n.1, p.54-63, 2008.

Hamilton, L.S., Stecher, B.M., Yuan, K. Standards-Based Reform in the United States: History, research, and future directions. [S.I.]: RANO Education, 2008. Available from: <http:// www.rand.org/content/dam/rand/pubs/reprints/2009/ RAND_RP1384.pdf>. Cited: Apr. 17, 2014. 
Harada, V.H.; Yoshina, J.M. Moving from rote to inquiry: Creating learning that counts. Library Media Connection, v.23, n.2, p.22-24, 2004.

Harris, B.R. Subversive infusions: Strategies for the integration of information literacy across the curriculum. The Journal of Academic Librarianship, v.39, n.2, p.175-180, 2013.

Hmelo-Silver, C.E. et al. Scaffolding and achievement in problem-based and inquiry learning: A response to Kirschner, Sweller, and Clark. Educational Psychologist, v.42, n.2, p.99-107, 2007.

Hernandez, F.; Montserrat, V. A construção do currículo por projetos de trabalhos: o conhecimento é um caleidoscópio. 5.ed. Porto Alegre: Artmed, 1998.

Hepworth, M.; Walton, G. Teaching information literacy for inquiry based learning. Cambridge: Woodhead Publishing, 2009.

Lau, J. Guidelines on information literacy for lifelong learning. Boca del Rio: IFLA, 2006. Available from: <http://www.ifla.org/ files/assets/information-literacy/publications/ifla-guidelinesen.pdf>. Cited: Apr. 17, 2014.

Lins, G.S. Inclusãoo do tema competência informacional e os aspectos tecnoloigicos relacionados, nos curriìculos de biblioteconomia e ciência da informação. 2007. Dissertação (Mestrado em Ciência da Informação) - Departamento de Ciência da Informação, Universidade de Brasília, Brasília, 2007. Disponível em: <http://repositorio.unb.br/bitstream/10482/1382/1/ Dissertacao_2007_Greyciane Lins.pdf>. Acesso em: 27 abr. 2014.

McKernan, J. Currículo e imaginação: teoria do processo, pedagogia e pesquisa-ação. Porto Alegre: Artmed, 2009.

McKinney, P. Information literacy and inquiry-based learning: Evaluation of a five-year programme of curriculum development. Journal of Librarianship and Information Science, v.0, n.0, p.1-19, 2013
Reed, S.L.; Stavreva, K. Layering knowledge: Information literacy as critical thinking in the literature classroom. Pedagogy, v.6, n.3, p.435-452, 2006.

Sancho, J.M. O currículo e os temas transversais: misturar água e azeite ou procurar uma nova "solução"? Pátio: Revista Pedagógica, v.2, n.5, p.12-17, 1998.

Saviani, N. Curriìculo: um grande desafio para o professor. Revista de Educação, n.16, p.35-38, 2003. Disponível em: <http:// files educar-e-uma-arte.webnode.com/20000080860ed861e7c/Curr\%C3\%ADc ulo\%20-\%20Um\%20grande\%20 desafio\%20para\%200\%20professor(1).pdf>. Acesso em: 8 maio 2016.

Stenhouse, L. An introduction to curriculum research and development. New Hampshire: Heinemann Educational Publishers, 1975.

Sousa, R.S.C.; Nascimento, B.S. Competências Informacionais: uma análise focada no currículo e na produção docente dos cursos de biblioteconomia e gestão da informação. Revista $A C B$, v.15, n.2, 2010. Disponível em: <http://revista.acbsc. org.br/racb/article/view/730>. Acesso em: 27 abr. 2014.

Westbrook, R.B. John Dewey. Prospects, v.23, n.1/2, p.277-291, 1993. Available from: <http://www.ibe.unesco.org/ publications/ThinkersPdf/deweye. PDF>. Cited:May 25, 2014.

$\mathrm{Yu}, \mathrm{H}$. et al. Integrating information literacy instruction (ILI) through resource-basead school projects: An interpretative exploration. Education for Information, v.28, n.2-4, p.247-268, 2011.

Yus Ramos, R. Temas transversais: a escola da ultramodernidade. Pátio: Revista Pedagógica, v.2, n.5, p.8-11, 1998.

Zabala, A. A prática educativa. Porto Alegre: Artmed, 1998.

Zabala, A. Enfoque globalizador e pensamento complexo: uma proposta para o currículo escolar. Porto Alegre: Artmed, 2002. 